\title{
Understanding the state of health policy and systems research in West Africa and capacity strengthening needs: scoping of peer-reviewed publications trends and patterns 1990-2015
}

Selina Defor, Aku Kwamie and Irene Akua Agyepong

\begin{abstract}
Background: The need for locally-driven, locally-generated evidence to guide health policy and systems decisionmaking and implementation in West Africa remains urgent. Thus, health policy and systems research (HPSR) is a field with great potential for addressing many of the sub-region's intransigent health challenges. This paper presents an analysis of trends and patterns of peer-reviewed HPSR publications across the Economic Community of West African States (ECOWAS), to help understand trends and patterns of HPSR publication and the degree of involvement of West African researchers in HPSR evidence generation in the sub-region. Our goal was to use the findings to inform the development of a sub-regional strategy to strengthen HPSR and its use to inform development and improvement of health outcomes.
\end{abstract}

Methods: A scoping review was conducted over a 25-year period from January 1990 to September 2015. Literature searches were conducted in English and French using Google Scholar, PubMed Central and Cairn.info.

Results: A total of 258 articles were retrieved. Of these, 246 were statistically analysed, with $54 \%$ having West African lead authors. Two thirds of the papers originated from three out of the 15 countries of the ECOWAS, specifically Nigeria (28.86\%), Burkina Faso (21.54\%) and Ghana (17.07\%). Most authors were based in academic institutions and participation of authors from ministries of health, hospitals and non-governmental organisations was limited. English was the predominant language for publication even for papers originating from Francophone West African countries. There has been a progressive increase in publications over the studied period.

Conclusion: Despite progressive improvements over time, West Africa remains a weak sub-region in terms of peerreviewed HPSR publications. Within the overall weakness, there is country-to-country variation. The fact that only a handful of countries accounted for nearly $70 \%$ of the total volume of publications in West Africa attests to the great disparities in individual, institutional and contextual capacities for HPSR evidence generation. Bridging the gap between lead institutions (universities and research centres) and the practice community (ministries, hospitals, nongovernmental organisations) is indispensable for ensuring the practical use of HPSR evidence. There remains a major need for investments in HPSR capacity building in West Africa.

*Correspondence: sellydel@yahoo.com

Ghana Health Service, Research and Development Division, Accra, Ghana 


\section{Background}

The pressing need to address weak and fragile health systems to achieve better health outcomes has been at the core of the global health agenda for over a decade. Nevertheless, achievement of the health-related Millennium Development Goals in West Africa has been greatly hampered by weak and poorly functioning health systems, among other challenges [1]. Health systems have been defined as comprising all actors, organisations, institutions and resources whose primary purpose is to improve health $[2,3]$. Apart from this defining goal, the health system has other intrinsic goals, namely (1) to be responsive to the population it serves (determined by the manner and the environment within which people are treated), and (2) to ensure a fair distribution of the financial burden of paying for health.

Health systems have been described as complex adaptive systems, given the fact that they are constantly adjusting in dynamic and unpredictable ways to changes within the system itself and/or in the broader context within which they operate [4]. This dynamism underscores the fact that pre-defined health system strengthening blueprints risk becoming ineffective beyond a certain time, and thus calls for regular production of evidence to inform national and local health systems development. Additionally, several studies have also accentuated the fact that evidence emanating from research can improve health policy development in terms of identifying issues for the policy agenda, informing policy decision and evaluating policy outcomes, and ultimately orienting efforts at strengthening health systems [5-8]. Health systems strengthening has been globally recognised as being critical to improving health outcomes, but the knowledge-base to support this effort in low- and middle-income countries (LMICs) has been rather weak.

Health policy and systems research (HPSR) is defined as a field that seeks to understand and improve how societies organise themselves in achieving collective health goals, and how different actors interact in the policy and implementation process to contribute to policy outcomes [9]. HPSR addresses health system and policy questions that are not disease specific, but concern systems problems that have repercussions on the performance of the entire health system. HPSR addresses a wide range of questions, from health financing, governance and policy, to problems with structuring, planning, management, human resources, service delivery, referral and quality of care in the public and private sector. Naturally, HPSR is a multidisciplinary field that blends economics, sociology, anthropology, political science, public health and epidemiology to draw a comprehensive picture of how health systems respond and adapt to health policies and how health policies are shaped by health systems and the broader determinants of health; it has policy as its focus and thus promotes work that explicitly seeks to influence policy $[10,11]$. It is worth noting that global interest and recognition of the importance of HPSR has been emphasised in several action-oriented reports and events in recent years [12-24]. According to some authors, commitment to HPSR and its application is reflected in the surge in international investment in the field in recent times [25]. Meanwhile, several other studies have repeatedly highlighted the persisting gap between high-income countries (HICs) and LMICs in terms of generation and use of HPSR [25-27]. This situation has caused some authors to question the rippleeffect of all global actions in support of the development of HPSR in LMICs [22, 27, 28].

West Africa, with an estimated population of approximately 350 million, comprises 15 countries (Benin, Burkina Faso, Cape Verde, Cote d'Ivoire, The Gambia, Ghana, Guinea, Guinea Bissau, Liberia, Mali, Nigeria, Niger, Sierra Leone, Senegal and Togo) all of which are classified as low or lower middle income [29].

The sub-region is home to an immense diversity of people, in terms of cultures, languages and religion. The complexities of the sub-region are layered in traditional ethnic, religious and language diversity, which is further heightened by the colonial legacy of fragmentation of the sub-region by official language into Anglophone, Francophone and Lusophone.

Compared to other regions, HPSR publications in West Africa have been woefully inadequate [26]. The weak health research production in the sub-region has been attributed not only to limited research capabilities and weak training capacities [30, 31], but also to weak capacities for resource mobilisation as well as limited capacity to develop research collaborations among countries within the sub-region [31, 32]. Despite having the potential to address most of the region's intransigent health challenges, the status of HPSR in West Africa has not been systematically studied.

The present study therefore aimed to scope the landscape and describe patterns and trends of Anglophone and Francophone HPSR publications across the Economic Community of West African States (ECOWAS) over the period 1990 to 2015. Our specific objectives were to describe trends, institutions, individuals and networks conducting HPSR, and the degree of West African-led involvement of researchers in HPSR evidence generation in the sub-region. The goal was to use the findings to inform the development of strategies to strengthen HPSR capacity, conduct and use for health systems strengthening and health outcome improvement within ECOWAS, including the establishment of HPSR networks. This paper focuses on the analysis of institutions and trends, and we do not present the analysis of individuals and networks. 


\section{Methods}

Our methodology was a scoping review of peer-reviewed publications over the 25-year period from January 1990 to September 2015. The theoretical foundations underlying this approach were based on the six-stage methodological framework developed by Arskey and O’Malley, which defines a scoping review as a "technique to map relevant literature in the field of interest". According to these authors, the scoping review is performed by (1) identifying the research question, (2) searching for relevant studies, (3) selecting studies, (4) charting the data, (5) collating, summarising and reporting the results, and (6) consulting with stakeholders to inform or validate the findings. The method is described as a knowledge synthesis approach that addresses an exploratory research question aimed at mapping evidence and gaps in research related to a given field through a systematic search, selection and synthesising of existing knowledge [33]. The review sought to identify and retrieve peer-reviewed HPSR publications on West Africa to understand patterns of Anglophone and Francophone HPSR publications, to identify individuals and institutions conducting HPSR, and to ascertain the degree of West African-led involvement of researchers in regional HPSR evidence generation. Thus, the scoping review was considered relevant for a study whose aim is to map the breadth rather than the depth of evidence in the field of HPSR in West Africa.

\section{Searching for and selecting relevant studies}

Literature searches were conducted in English and French using Google Scholar, PubMed Central and Cairn.info. Inclusion criteria were peer-reviewed publications from work conducted in any of the 15 ECOWAS member states published in English or French, whose objectives and/or keywords explicitly included mention of health systems or one or more of the WHO health systems building blocks. Apart from Cape Verde and Guinea Bissau, which are
Portuguese-speaking, the remaining 13 countries of ECOWAS are English or French speaking. However, we did not have the language expertise to review the Portuguese literature.

Search terms employed were initially limited to "health systems" AND "name of ECOWAS country", "health policy systems research" AND "West Africa", "health systems research" AND "West Africa" or "name of ECOWAS country" and "health policy" AND "name of ECOWAS country". These were later expanded to include "health care financing" AND "West African country", "health service delivery" AND "West African country", "health leadership" OR "governance" AND "West African country", "health information systems" AND "West African country", "health care" AND "human resource" AND "West African country". French search terms employed were: Prestations services + soin de santé + Afrique de l'Ouest/ un pays de l'Afrique de l'Ouest, Accès + soin + Afrique de l'Ouest, Accès + soin + un pays de l'Afrique de l'Ouest, Personnels de santé + Afrique de l'Ouest/un pays de l'Afrique de l'Ouest, Politiques pharmaceutique + Afrique de l'Ouest/un pays de l'Afrique de l'Ouest, système d'information santé + Afrique de l'Ouest/un pays de l'Afrique de l'Ouest.

Figure 1 illustrates the flow diagram of inclusion of articles in the scoping review.

\section{Charting the data, collating, summarising and reporting the results}

All eligible articles were downloaded and saved in an Endnote library. The data were compiled and imported in Microsoft Excel for validation and coding. From each publication included in the study, we extracted the following variables: language of publication, year of publication, study location, country in which the primary institution of the first author and co-authors were based, type of institution of the first author and co-authors

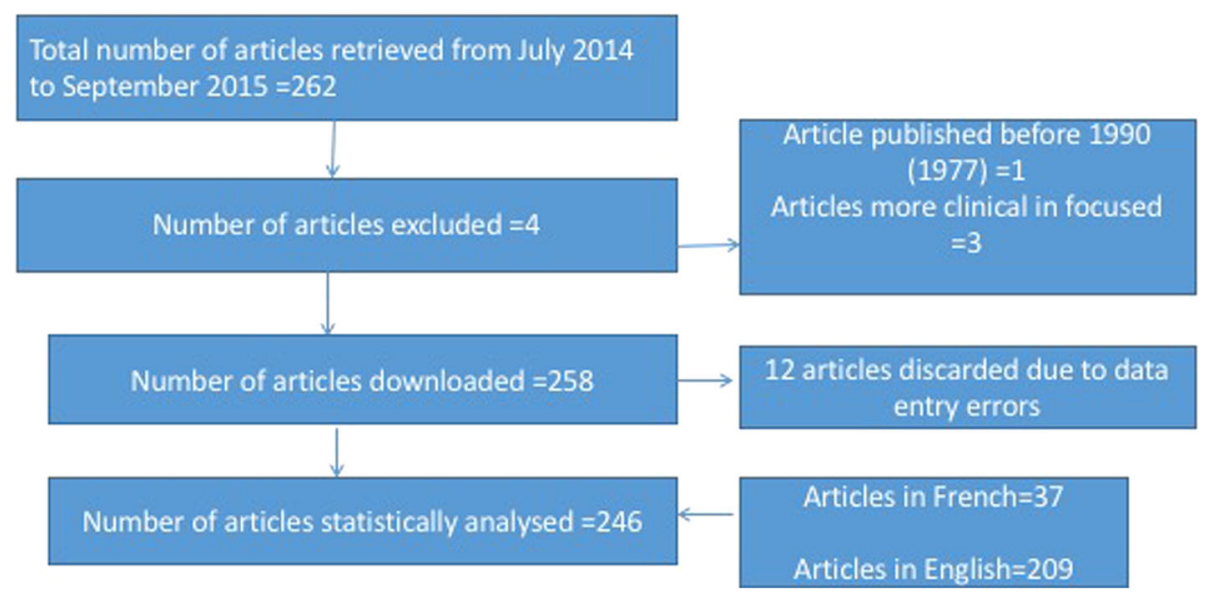

Fig. 1 Flow diagram of inclusion 
(university, institute or research centre, hospital, nongovernmental organisation or other), and number of West African first authors. We conducted some of the analysis in Excel and exported the data into STATA version 12 for further analysis.

\section{Consulting with stakeholders to inform or validate the findings}

Consultation with stakeholders to validate the findings was performed at two sub-regional meetings. The first was a consultative ECOWAS health research strategic plan validation meeting of senior health researchers organised by the West African Health Organization (WAHO) in Abidjan in February 2015. Present at the meeting were senior researchers from universities, health research institutes and ministries of health across the ECOWAS sub-region. The second validation meeting was the inception meeting of the young West African health policy and systems researchers and implementers support network, known as the West African Network of Emerging Leaders organised in Accra in June 2015.

The search continued after the second validation meeting, from June to September 2015. The extension of the scoping and the addition of the WHO's six health systems building blocks, and their sub-components, to define the scope of the review was due to the feedback from these two stakeholder validation meetings. The initial search, apart from stopping at 2014, had been narrowly limited to "health systems" OR "health policy" AND "name of ECOWAS country". This narrow approach had yielded only 65 publications. In both validation workshops, respondents pointed out missing papers. To avoid bias, since not all possible researchers were members of these validation meetings, it was not considered advisable to add the papers they pointed out as missing, without making sure they met an objectively defined search inclusion criteria. The expansion of the search terms raised the number of papers to 262. It also dealt with most, but not necessarily all, of the missing papers indicated. However, for fairness in the comparative and trend analysis, we retained 246 papers, whilst acknowledging it is not an exhaustive list.

\section{Ethical considerations}

This was a desk review of published literature already in the public domain. No primary data collection or analysis was carried out. There was therefore no need to seek ethical clearance or informed consent.

\section{Results}

After reviewing the title, keywords and abstract of the papers retrieved, we included 246 articles from 14 out of the 15 West African countries in the analysis.

\section{Publication trends}

Figure 2 shows the total publications by year over the study period. The almost flat number of publications per year starts to show a slow rise in number of publications per year from 2001 onwards, which further accelerates from 2006 onwards.

\section{Publication by country location of the study}

The observed growth in publications was due to the high volumes of publications from just a few countries. During the period reviewed, all the West African countries produced at least one HPSR-related article. Apart from Burkina Faso, which stands out considerably, the five Anglophone West African countries seemed to be publishing more than the majority of Francophone West African countries. Nigeria was the highest producing country, with a publication volume of $28.86 \%(n=71)$ of the total regional production, followed by Burkina Faso $(21.54 \% ; n=53)$ and Ghana (17.07\%; $n=42)$. Indeed, Nigeria, Ghana and Burkina Faso alone accounted for more than two thirds of the articles retrieved.

When the publications over the period of review were related to the 2015 mid-year population, the difference between Anglophone and Francophone countries in terms of density of publications in relation to population was marked. Burkina Faso had the highest number of publications per million population. In this regard

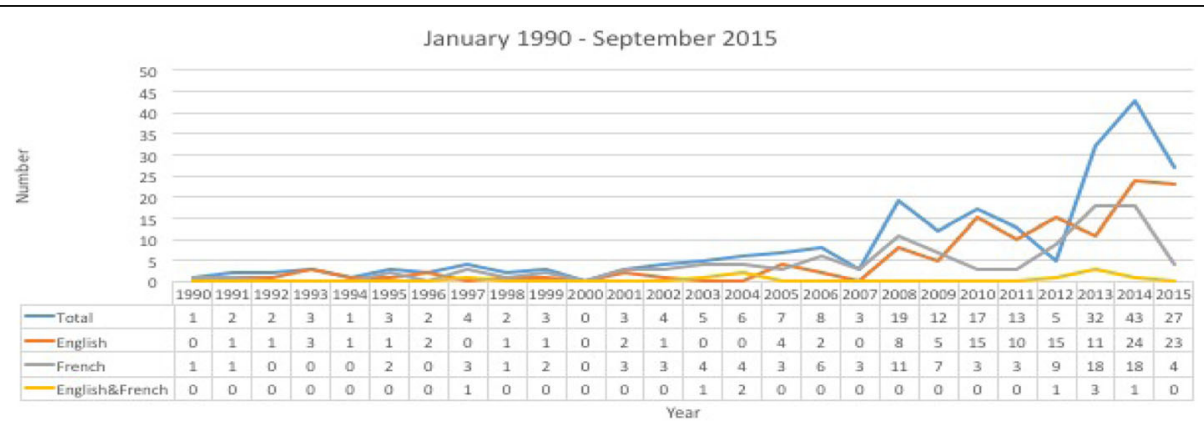

Fig. 2 Trends in peer reviewed publications focused on Health Policy and Systems from West Africa 
Nigeria, dropped close to the bottom of the list. Some of the smaller countries, such as Sierra Leone and The Gambia, showed a relatively high density (Table 1 ).

\section{Lead authorship and country of affiliation}

Overall, 54\% $(n=132)$ of the papers had a West African as the lead author. Table 2 summarises West African lead authors by country. However, there were many cases where, despite the lead author being West African, their primary affiliation was a non-West African institution, which accounted for the higher number of non-West African lead institutions compared to West African lead individuals. Generally, this was due to the lead authors being registered as $\mathrm{PhD}$ researchers in the Northern institution.

\section{Institution of affiliation of lead author}

Table 3 outlines details of the institution of affiliation of the lead author as well as the country in which the institute is located. The six most frequent institutions of affiliation of lead authors were University of Montreal (8.5\%), University of Heidelberg (7.3\%), University of Ghana and University of Nigeria (4.1\% each), Johns

Table 1 Publications by country over the 25-year period per $1,000,000$ of 2015 estimated population

\begin{tabular}{|c|c|c|c|c|}
\hline $\begin{array}{l}2015 \text { estimated } \\
\text { mid-year }\end{array}$ & $\begin{array}{l}\text { Population } \\
\text { Popo }\end{array}$ & $\begin{array}{l}\% 2015 \\
\text { pop }\end{array}$ & Publications & $\begin{array}{l}\text { Per } 1,000,000 \\
\text { of } 2015 \\
\text { estimated } \\
\text { population }\end{array}$ \\
\hline Nigeria & $183,523,432$ & $53 \%$ & 70 & 0.381 \\
\hline Ghana & $26,984,328$ & $8 \%$ & 41 & 1.519 \\
\hline Côte d'Ivoire & $21,295,284$ & $6 \%$ & 6 & 0.282 \\
\hline Niger & $19,268,380$ & $6 \%$ & 6 & 0.311 \\
\hline Burkina Faso & $17,914,625$ & $5 \%$ & 53 & 2.958 \\
\hline Mali & $16,258,587$ & $5 \%$ & 11 & 0.677 \\
\hline Senegal & $14,967,446$ & $4 \%$ & 9 & 0.601 \\
\hline Guinea & $12,347,766$ & $4 \%$ & 3 & 0.243 \\
\hline Benin & $10,879,828$ & $3 \%$ & 10 & 0.919 \\
\hline Togo & $7,170,797$ & $2 \%$ & 1 & 0.139 \\
\hline Sierra Leone & $6,318,575$ & $2 \%$ & 11 & 1.741 \\
\hline Liberia & $4,503,439$ & $1 \%$ & 3 & 0.666 \\
\hline Gambia & $1,970,081$ & $1 \%$ & 3 & 1.523 \\
\hline Guinea-Bissau & $1,787,793$ & $1 \%$ & 1 & 0.559 \\
\hline Cape Verde & 508,315 & $0 \%$ & 0 & 0.000 \\
\hline Total Population WA & $345,698,676$ & $100 \%$ & & 0.000 \\
\hline Several West African & & & 13 & 0.038 \\
\hline Several African & & & 4 & 0.012 \\
\hline \multirow[t]{2}{*}{ Multi International } & & & 1 & 0.003 \\
\hline & & & 246 & 0.712 \\
\hline
\end{tabular}

Hopkins University (2.8\%) and University of Columbia (2\%).

Most lead authors (162/246) were affiliated with a university; $62 \%$ of these universities $(100 / 162)$ were in the global North and 38\% in West Africa. Northern universities were dominated by University of Montreal, which was the lead in 21 out of the 100 (21\%) Northern institution leads, followed by University of Heidelberg (18/100). The West African universities were dominated by University of Ghana (10/63) and University of Nigeria (10/63).

When the Northern and the West African universities were combined in the analysis, the top five universities as affiliation of lead author were Montreal (14\%), Heidelberg (11\%), University of Ghana (6\%), University of Nigeria (6\%) and John Hopkins School of Public Health (4\%).

Research institutes formed the next largest group of institutions (37/246). Most of these research institutes $(27 / 37 ; 73 \%)$ were in West Africa, while the rest were in the North (Table 4), which is the reverse of the situation with universities. The Institute of Tropical Medicine in Antwerp was the institution of the lead author in 4 out of the 10 leader authors from Northern research institutes. Of the West African research institutes, the Navrongo Health Research Center in Ghana and the Centre de Recherche en Santé de Nouna in Burkina Faso led in publications, with six

Table 2 West African Lead Authors by country in which research was conducted

\begin{tabular}{llll}
\hline Country & No. Papers & $\begin{array}{l}\text { No with } \\
\text { West } \\
\text { African lead } \\
\text { author }\end{array}$ & $\begin{array}{l}\text { \% with } \\
\text { West } \\
\text { African } \\
\text { lead author }\end{array}$ \\
\hline Benin & 10 & 8 & $80 \%$ \\
Burkina Faso & 53 & 14 & $26 \%$ \\
Cote d'Ivoire & 6 & 5 & $83 \%$ \\
Gambia & 3 & 1 & $33 \%$ \\
Ghana & 42 & 31 & $74 \%$ \\
Guinea & 3 & 0 & $0 \%$ \\
Guinea Bissau & 1 & 0 & $0 \%$ \\
Liberia & 2 & 0 & $0 \%$ \\
Mali & 12 & 1 & $8 \%$ \\
Niger & 5 & 3 & $60 \%$ \\
Nigeria & 71 & 59 & $83 \%$ \\
Senegal & 9 & 5 & $56 \%$ \\
Sierra Leone & 11 & 0 & $0 \%$ \\
Togo & 1 & 0 & $0 \%$ \\
Multi country West Africa & 14 & 5 & $36 \%$ \\
Multi country Africa & 2 & 0 & $0 \%$ \\
Multi country international & 1 & 0 & $0 \%$ \\
Total & 246 & 132 & $54 \%$ \\
\hline
\end{tabular}


Table 3 Details Institution of Lead author (detail)

\begin{tabular}{|c|c|c|c|}
\hline Institution of lead author & $\begin{array}{l}\text { Country of } \\
\text { institution }\end{array}$ & Number & $\begin{array}{l}\% \text { of all } \\
\text { institutions }\end{array}$ \\
\hline \multicolumn{4}{|c|}{ SOUTHERN (WEST AFRICAN) UNIVERSITIES } \\
\hline University of Ghana & Ghana & 10 & $4.1 \%$ \\
\hline University of Nigeria & Nigeria & 10 & $4.1 \%$ \\
\hline University of Calabar & Nigeria & 4 & $1.6 \%$ \\
\hline Nnamdi Azikiwe University & Nigeria & 4 & $1.6 \%$ \\
\hline University of Lagos & Nigeria & 3 & $1.2 \%$ \\
\hline University of Ibadan & Nigeria & 3 & $1.2 \%$ \\
\hline Ahmadu Bello University & Nigeria & 2 & $0.8 \%$ \\
\hline Cheikh Anta Diop University & Senegal & 2 & $0.8 \%$ \\
\hline Ebonyi State University & Nigeria & 2 & $0.8 \%$ \\
\hline L'Universite de Ouagadougou & $\begin{array}{l}\text { Burkina } \\
\text { Faso }\end{array}$ & 1 & $0.4 \%$ \\
\hline Olabisi Onabanjo University & Nigeria & 2 & $0.8 \%$ \\
\hline Nnamdi Azikiwe University & Nigeria & 3 & $1.2 \%$ \\
\hline Bayero University & Nigeria & 1 & $0.4 \%$ \\
\hline Ekiti State University & Nigeria & 1 & $0.4 \%$ \\
\hline $\begin{array}{l}\text { Kwame Nkrumah University of } \\
\text { Science and Technology }\end{array}$ & Ghana & 1 & $0.4 \%$ \\
\hline Niger Delta University & Nigeria & 1 & $0.4 \%$ \\
\hline ObafemiAwolowo University & Nigeria & 1 & $0.4 \%$ \\
\hline University of Abomey-Calavi & Benin & 1 & $0.4 \%$ \\
\hline Federal University of Agriculture & Nigeria & 1 & $0.4 \%$ \\
\hline $\begin{array}{l}\text { University of Benin Teaching } \\
\text { Hospital }\end{array}$ & Benin & 1 & $0.4 \%$ \\
\hline University of Cape Coast & Ghana & 1 & $0.4 \%$ \\
\hline University of Cocody & $\begin{array}{l}\text { Cote } \\
\text { d'Ivoire }\end{array}$ & 2 & $0.8 \%$ \\
\hline Delta State University & Nigeria & 1 & $0.4 \%$ \\
\hline $\begin{array}{l}\text { University of Development } \\
\text { studies }\end{array}$ & Ghana & 1 & $0.4 \%$ \\
\hline University of Ilorin & Nigeria & 1 & $0.4 \%$ \\
\hline University of Jos & Nigeria & 1 & $0.4 \%$ \\
\hline \multirow[t]{2}{*}{ University of Sokoto, Nigeria } & Nigeria & 1 & $0.4 \%$ \\
\hline & & 62 & $25.2 \%$ \\
\hline \multicolumn{4}{|l|}{ NOTHERN UNIVERSITIES } \\
\hline $\begin{array}{l}\text { Universite de Montreal/University } \\
\text { of Montreal }\end{array}$ & Canada & 21 & $8.5 \%$ \\
\hline University of Heidelberg & Germany & 18 & $7.3 \%$ \\
\hline John Hopkins University & USA & 7 & $2.8 \%$ \\
\hline Colombia University & USA & 5 & $2.0 \%$ \\
\hline $\begin{array}{l}\text { London School of Hygiene \& } \\
\text { Tropical Medicine }\end{array}$ & UK & 4 & $1.6 \%$ \\
\hline $\begin{array}{l}\text { The University of Western } \\
\text { Ontario }\end{array}$ & Canada & 4 & $1.6 \%$ \\
\hline $\begin{array}{l}\text { Norwegian University of Science } \\
\text { and Technology }\end{array}$ & Norway & 3 & $1.2 \%$ \\
\hline University of Aberdeen & UK & 3 & $1.2 \%$ \\
\hline
\end{tabular}

Table 3 Details Institution of Lead author (detail) (Continued)

\begin{tabular}{|c|c|c|c|}
\hline University of California & USA & 3 & $1.2 \%$ \\
\hline $\begin{array}{l}\text { London School of Economics } \\
\text { and Political Science }\end{array}$ & UK & 2 & $0.8 \%$ \\
\hline University of Ottawa & Canada & 2 & $0.8 \%$ \\
\hline University of Washington & USA & 2 & $0.8 \%$ \\
\hline King's College London & UK & 2 & $0.8 \%$ \\
\hline Radboud University Nijmegen & Netherlands & 2 & $0.8 \%$ \\
\hline Université Claude Bernard & France & 2 & $0.8 \%$ \\
\hline $\begin{array}{l}\text { Liverpool School of Tropical } \\
\text { Medicine }\end{array}$ & UK & 2 & $0.8 \%$ \\
\hline $\begin{array}{l}\text { Ernst-Moritz-Arndt-Universität } \\
\text { Greifswald (University of } \\
\text { Greifswald) }\end{array}$ & Germany & 2 & $0.8 \%$ \\
\hline University of Illinois & USA & 1 & $0.4 \%$ \\
\hline Aarhus University & Denmark & 1 & $0.4 \%$ \\
\hline $\begin{array}{l}\text { Institut d'etudes politiques de } \\
\text { Grenoble }\end{array}$ & France & 1 & $0.4 \%$ \\
\hline $\begin{array}{l}\text { Graduate Institute of International } \\
\text { and Development Studies }\end{array}$ & Switzerland & 1 & $0.4 \%$ \\
\hline McGill University & Canada & 1 & $0.4 \%$ \\
\hline Université Catholique de Louvain & Belgium & 1 & $0.4 \%$ \\
\hline University of Alabama & USA & 1 & $0.4 \%$ \\
\hline University of Birmingham & UK & 1 & $0.4 \%$ \\
\hline University of North Carolina & USA & 1 & $0.4 \%$ \\
\hline University of Sydney & Australia & 1 & $0.4 \%$ \\
\hline University of Toronto & Canada & 1 & $0.4 \%$ \\
\hline University of Western Australia & Australia & 1 & $0.4 \%$ \\
\hline Hebrew University, Jerusalem & North & 1 & $0.4 \%$ \\
\hline Vrije Universitat Amsterdam & Netherlands & 1 & $0.4 \%$ \\
\hline Concordia University & Canada & 1 & $0.4 \%$ \\
\hline \multirow[t]{2}{*}{ Yale School of Public Health } & USA & 1 & $0.4 \%$ \\
\hline & & 100 & $40.7 \%$ \\
\hline
\end{tabular}

NORTHERN RESEARCH INSTITUTES AND GROUPS (NON UNIVERSITY)

\begin{tabular}{|c|c|c|c|}
\hline $\begin{array}{l}\text { Institut français de recherche } \\
\text { scientifique pour le } \\
\text { développement en coopération }\end{array}$ & North & 1 & $0.4 \%$ \\
\hline Centre de Recherche Warocqué & Belgium & 1 & $0.4 \%$ \\
\hline $\begin{array}{l}\text { Institute for Medical Technology } \\
\text { Assessment }\end{array}$ & Netherlands & 1 & $0.4 \%$ \\
\hline Institute of Development Studies & UK & 1 & $0.4 \%$ \\
\hline $\begin{array}{l}\text { Institute of Tropical Medicine- } \\
\text { Antwerp }\end{array}$ & Belgium & 4 & $1.6 \%$ \\
\hline $\begin{array}{l}\text { Memorial Sloan-Kettering Cancer } \\
\text { Center }\end{array}$ & USA & 1 & 0.4 \\
\hline \multirow[t]{2}{*}{ Royal Tropical Institute } & Netherlands & 1 & $0.4 \%$ \\
\hline & & 10 & $4.1 \%$ \\
\hline
\end{tabular}

SOUTHERN RESEARCH INSTITUTES AND GROUPS (NON UNIVERSITY)

Burkina $\quad 6 \quad 2.4 \%$
Faso 
Table 3 Details Institution of Lead author (detail) (Continued)

\begin{tabular}{|c|c|c|c|}
\hline $\begin{array}{l}\text { Navrongo Health Research } \\
\text { Centre }\end{array}$ & Ghana & 6 & $2.4 \%$ \\
\hline $\begin{array}{l}\text { Institut régional de santé } \\
\text { publique }\end{array}$ & Benin & 4 & $1.6 \%$ \\
\hline $\begin{array}{l}\text { Centre de Recherche en Santé de } \\
\text { Nouna }\end{array}$ & $\begin{array}{l}\text { Burkina } \\
\text { Faso }\end{array}$ & 2 & $0.8 \%$ \\
\hline $\begin{array}{l}\text { Laboratoire d'Etudes et de } \\
\text { Recherche sur les Dynamiques } \\
\text { Sociales et le Développement } \\
\text { Local }\end{array}$ & Niger & 2 & $0.8 \%$ \\
\hline $\begin{array}{l}\text { African Population and Health } \\
\text { Research institute }\end{array}$ & Kenya & 1 & $0.4 \%$ \\
\hline $\begin{array}{l}\text { Consortium de Recherche en } \\
\text { Economie Sociale }\end{array}$ & Senegal & 1 & $0.4 \%$ \\
\hline $\begin{array}{l}\text { Ecole Nationale Supérieure de } \\
\text { Statistiques et d'Economie } \\
\text { Appliquée }\end{array}$ & $\begin{array}{l}\text { Cote } \\
\text { d'Ivoire }\end{array}$ & 1 & $0.4 \%$ \\
\hline $\begin{array}{l}\text { Institut de recherche en sciences } \\
\text { de la santé }\end{array}$ & $\begin{array}{l}\text { Burkina } \\
\text { Faso }\end{array}$ & 1 & $0.4 \%$ \\
\hline $\begin{array}{l}\text { Institut National de Recherches } \\
\text { en Santé Publique }\end{array}$ & Mali & 1 & $0.4 \%$ \\
\hline $\begin{array}{l}\text { Institut de Recherche en Science } \\
\text { de la Santé }\end{array}$ & $\begin{array}{l}\text { Burkina } \\
\text { Faso }\end{array}$ & 1 & $0.4 \%$ \\
\hline \multirow{2}{*}{$\begin{array}{l}\text { Public Health Research \& } \\
\text { Development Centre }\end{array}$} & \multirow[t]{2}{*}{ Gambia } & 1 & $0.4 \%$ \\
\hline & & 27 & $11.0 \%$ \\
\hline \multicolumn{4}{|l|}{ NORTHERN INSTITUTES - ALL OTHERS } \\
\hline $\begin{array}{l}\text { Center for Disease Control, } \\
\text { Atlanta }\end{array}$ & USA & 4 & $1.6 \%$ \\
\hline Africa Development Bank & Multilateral & 3 & $1.2 \%$ \\
\hline Abt Associates & USA & 3 & $1.2 \%$ \\
\hline Astellas Pharma UK Ltd & UK & 2 & $0.8 \%$ \\
\hline ICF International & USA & 2 & $0.8 \%$ \\
\hline $\begin{array}{l}\text { United Nations Children } \\
\text { Emergency Fund }\end{array}$ & Multilateral & 2 & $0.8 \%$ \\
\hline Massachusetts General Hospital & USA & 1 & $0.4 \%$ \\
\hline $\begin{array}{l}\text { German Development } \\
\text { Cooperation }\end{array}$ & Germany & 1 & $0.4 \%$ \\
\hline United States Peace Corps & USA & 1 & $0.4 \%$ \\
\hline World Bank & Multilateral & 1 & $0.4 \%$ \\
\hline Institut de Veille sanitaire & France & 1 & $0.4 \%$ \\
\hline Family Care International & USA & 1 & $0.4 \%$ \\
\hline Helen Keller International & USA & 1 & $0.4 \%$ \\
\hline Save the Children & USA & 1 & $0.4 \%$ \\
\hline Surgeons OverSeas & USA & 1 & $0.4 \%$ \\
\hline \multirow[t]{2}{*}{ University Research Co. } & USA & 1 & $0.4 \%$ \\
\hline & & 26 & $10.6 \%$ \\
\hline \multicolumn{4}{|l|}{ SOUTHERN INSTITUTES - ALL OTHERS } \\
\hline Ghana Health Service & Ghana & 4 & $1.6 \%$ \\
\hline $\begin{array}{l}\text { National Primary Health Care } \\
\text { Development agency }\end{array}$ & Nigeria & 2 & $0.8 \%$ \\
\hline Agogo Presbyterian Hospital & Ghana & 1 & $0.4 \%$ \\
\hline
\end{tabular}

Table 3 Details Institution of Lead author (detail) (Continued)

\begin{tabular}{llll}
\hline Aminu Kano Teaching Hospital & Nigeria & 1 & $0.4 \%$ \\
Federal Medical Centre & Nigeria & 1 & $0.4 \%$ \\
$\begin{array}{l}\text { Institut National de Santé } \\
\text { Publique }\end{array}$ & $\begin{array}{l}\text { Cote } \\
\text { d'Ivoire }\end{array}$ & 1 & $0.4 \%$ \\
$\begin{array}{l}\text { Irrua Specialist Teaching Hospital } \\
\text { Komfo Anokye Teaching Hospital }\end{array}$ & Ghana & 1 & $0.4 \%$ \\
National Hospital & Nigeria & 1 & $0.4 \%$ \\
$\begin{array}{l}\text { Federal Ministry of Health, Abuja } \\
\text { Ministère de la Santé et de }\end{array}$ & Nigeria & 1 & $0.4 \%$ \\
I'Hygiène Publique & Cote & 1 & $0.4 \%$ \\
$\begin{array}{l}\text { Ministère de la santé publique/ } \\
\text { Mission de coopération }\end{array}$ & Niger & 1 & $0.4 \%$ \\
$\begin{array}{l}\text { Burkinabe Public Health } \\
\text { Association }\end{array}$ & Burkina & 1 & $0.4 \%$ \\
$\begin{array}{l}\text { Cellule d'Analyse et de } \\
\text { Prospective en Développement }\end{array}$ & Naso & & \\
$\begin{array}{l}\text { Partnership for Reviving Routine } \\
\text { Immunisation in Northern- }\end{array}$ & Nigeria & 1 & $0.4 \%$ \\
$\begin{array}{l}\text { Maternal Newborn and Child } \\
\text { Health }\end{array}$ & & & \\
$\begin{array}{l}\text { Mediplan healthcare limited } \\
\text { Nigeria Reinsurance Corporation }\end{array}$ & Nigeria & 1 & $0.4 \%$ \\
$\begin{array}{l}\text { Total } \\
\text { Nigeria }\end{array}$ & 1 & $0.4 \%$ \\
\hline
\end{tabular}

publications each. The Institut Régional de Santé Publique in Benin followed, with four publications. The culture of research institutions appears to be particularly strong in Ghana and Burkina Faso.

Universities alone accounted for more than two-thirds of the total publications, though the relevance of HPSR publication is dependent on its ability to influence policy and practice. It appears practitioners are less involved in the production of HPSR knowledge in West Africa. Stronger lead involvement of ministries of health and government agencies and even non-governmental organisations in HPSR evidence generation needs to be encouraged across the sub-region. There is much that other countries in the sub-region will be able to learn from Ghana in this regard (10 publications from the Ghana Health Service, with six from the Navrongo Health Research Center and four from other parts of the service). The Ghana publications from within the health service were generally led by Ghanaian researchers. Burkina Faso also has some lead in this area, despite the strong dominance of Northern researchers in the papers coming out of Burkina Faso.

\section{Language of publication}

Even though French is widely spoken in the sub-region, most publications (84.96\%) were in English, including publications from work performed in Francophone 
Table 4 Summary of Institution of Lead author

\begin{tabular}{llll}
\hline Type of Institution & Location & & \\
\cline { 2 - 4 } & $\begin{array}{l}\text { Northern } \\
\text { (\% type of } \\
\text { institution) }\end{array}$ & $\begin{array}{l}\text { Southern } \\
\text { (\% type of } \\
\text { institution) }\end{array}$ & $\begin{array}{l}\text { Total } \\
\text { (\% of all } \\
\text { institutes) }\end{array}$ \\
\hline $\begin{array}{l}\text { Government } \\
\text { Agency } \\
\text { Hospital }\end{array}$ & $6(40 \%)$ & $9(60 \%)$ & $15(6 \%)$ \\
$\begin{array}{l}\text { International } \\
\text { bilateral }\end{array}$ & $1(14 \%)$ & $6(86 \%)$ & $7(3 \%)$ \\
$\begin{array}{l}\text { International Multi } \\
\text { lateral }\end{array}$ & $6(100 \%)$ & $0(0 \%)$ & $1(0.4 \%)$ \\
$\begin{array}{l}\text { NGO/Private } \\
\text { Private (Other) }\end{array}$ & $11(73 \%)$ & $4(27 \%)$ & $15(6 \%)$ \\
Research Institute & $10(27 \%)$ & $27(67 \%)$ & $3(1 \%)$ \\
University & $100(62 \%)$ & $62(38 \%)$ & $37(15 \%)$ \\
Total & $136(55 \%)$ & $110(45 \%)$ & $246(100 \%)$ \\
\hline
\end{tabular}

countries, and the one publication for Guinea Bissau, a Lusophone country.

\section{Discussion}

This study confirms the observation of increased interest in HPSR globally as of 2008 [25]. Similarly, the publication rate within ECOWAS began accelerating significantly from 2008. This growth in peer-reviewed publications could be due to several factors. We speculate that perhaps the Mexico Summit in 2004, the first high-level ministerial discussion that placed health research back on the global health agenda, may have contributed. The series of global health research for a, including their action-oriented outcome documents and the activities leading to the Second Ministerial Forum in 2008, which was shortly followed by the First Global Symposium on Health Systems Research in 2010, may have all heightened the interest and recognition of the value of HPSR. A total of 33 articles were published between 1991 and 2003, the first 12 years preceding the 2004 Mexico Summit. The picture improved with a sixfold increase in publication over the next 12-year period, from 2004 to 2015, with a total of 212 publications.

Multiple global events and actions that emphasised the importance of health research for health systems strengthening for improved health outcomes may also have contributed. These are notably the Global Fora for Health Research and the Call to Action [14, 19, 20], the WHO Strategy on Research for Health [24], and the release of the United Kingdom DFID Research Strategy 2008-2013 [17], which emphasised the need to build research capacity for African countries to be able to identify their priority health needs and respond accordingly. Recognising the need to develop national level multidisciplinary research capacity, the European Union made considerable investments in country-led research and knowledge generation efforts. With a budget of $€ 6$ billion under the Framework Programme 7, the European Union encouraged research collaborations with LMICs for cooperative health-research programmes and identified research on optimising healthcare delivery as one of the three priority areas [12].

Although HPSR publication output steadily increased in West Africa during the period reviewed, the volume remains minimal, and the longstanding gap between LMICs and HICs remains. With a publications volume of 212 from 2004 to 2015, West Africa is lagging far behind other regions. A similar HPSR stock-taking exercise conducted in the Eastern Mediterranean region over an 8-year period (2000-2008) showed a publication volume of 1489. The least producing country in this region (Yemen) produced just the same volume $(n=71)$ as the highest producing country (Nigeria; $n=71$ ) in West Africa. A study that examined trends in international HPSR publications concluded that it will take more than 42 years for HPSR publications relative to the global South to reach the current rate of the global North at current publication rates [34]. Several factors may have accounted for this persisting gap in HPSR outputs in LMICs.

First, financial resource constraints, particularly a lack of national funding for health research, have been commonly identified as one of the major factors impeding HPSR productivity in LMICs [35] and holds true for West Africa. Despite all the international commitments to increasing domestic resources for health research, very few national resources are applied to any kind of health research in the sub-region, including HPSR [25]. A survey conducted by WAHO revealed that only onethird of the West African countries had put in place strategies to implement the international recommendation for the allocation of $2 \%$ of Ministry of Health budget and $5 \%$ of project budgets to research [31]. Most Ministry of Health budget documents audited had no budget line to support projects of the research for health apparatus within the Ministry of Health. Several studies have documented the fact that international multilateral and bilateral aid are the main funding source for HPSR through project grants in LMICs [36, 37]. However, LMIC institutions are less likely to receive core funding than institutions based in HICs [25]. External donor resources are a potential source of HPSR funding for ECOWAS member states, but unfortunately the capacity to develop strong proposals to compete for these funds is also weak in West Africa, limiting opportunities to tap into international competitive funding opportunities for HPSR [25].

Secondly, HPSR is context-specific and requires local actors with an understanding and appreciation of their 
own health systems challenges to drive the processes of evidence generation and application for health policy and systems, and ultimately health outcome improvement. This can only be the case on condition that the local actors have the requisite capacity. Capacity involves the ability of individuals, institutions and societies to perform functions, solve problems, and set and achieve objectives in a sustainable manner [38]. More specifically, HPSR capacity involves expertise and resources at the researcher, project and institutional levels to produce new knowledge and applications to improve the social response to health problems [39]. Regrettably, several studies have emphasised the weak and non-existing capacity for HPSR activities in LMICs [25]. The lack of capacity to produce HPSR in West Africa is clearly substantiated in this scoping review. The majority of the countries are producing very negligible amounts of HPSR publications, with the few who are producing a fair amount owing the volume of their publications to non-West African authors or West African lead author affiliation with institutions outside the region.

Third, apart from the weak individual and institutional capacities, the broader context within which the local researchers operate provides a disincentive to health research in general, including HPSR. A study carried out by WAHO also revealed that only $50 \%$ of West African countries have directorates within their ministries of health to oversee research for health, as well as strategic documents that outline health research priorities that include health systems-related issues [31]. Only five countries had national ethics committees with members trained in research ethics. Additionally, government health officials also lacked adequate capacity to support the translation of research findings into policy and practice, thus limiting the utility of the evidence generated. This further dwindled enthusiasm for the generation of more evidence.

Clearly, HPSR capacity needs strengthening in West Africa. There is scarce evidence on the most effective capacity strengthening initiative; however, various forms of in-country, cross-country, intra-regional and international collaborations have helped to strengthen research capacity and increased research productivity in several LMICs, including some of the stronger countries in West Africa, and the entire sub-region could learn from them. For example, the Medical Education Partnership Initiative in Nigeria, a consortium of six Nigerian universities working in partnership with two universities in the United States, built the research capacity of more than 1600 faculty, graduate students and resident doctors, between 2011 and 2013, through a train-thetrainers programme. The American partners train incountry resources persons, approximately six in each member university in nine different courses, who in turn replicated the workshops in their various institutions as part of a regular career development programme, using the same training materials. This improved capacity has not only led to increased number of publications in peer-reviewed journals but also increased responses to local and international grant applications and awards [40]. Additionally, collaboration between Thailand and South Africa with support from the United Kingdom moderately strengthened institutional capacity in South Africa, but led to significant individual research capacity strengthening. Capacity-building activities implemented during this collaboration included post-graduate training, joint proposal development, publication and dissemination of research results, staff secondment, mentorship and exchanges [41].

In the Southern Africa Development Community, a South-South collaboration between the region's Center of Excellence for Biomedical Research and Training and Zimbabwe's Blair Research Laboratory with support from the Danish Bilharziasis Laboratory helped build research capacities in Zimbabwe and other African institutions through doctoral-level training and joint research projects [42]. Finally, research capacity around social determinants of health was strengthened in several LMICs (Brazil, Colombia, Mexico, Kenya, South Africa and Tanzania) through a triangulation of South-NorthSouth collaborative networks (SDH-NET) in partnership with Spain, Switzerland, the United Kingdom and Germany [43].

Several studies have also found a strong relationship between international research cooperation and increased scientific productivity [44-46]. They argued that the complexities involved in research require more specialised knowledge that no individual or a single country is expected to have. Thus, collaboration allows individuals to play to their strong suits, contributing their strongest skills and deepest knowledge, while relying on others to contribute other skills and knowledge [47]. At the macro-level, collaboration will enable institutions and countries to mobilise and use their differentiated capabilities to enhance the knowledge creation process towards increased productivity.

\section{Limitations of the study}

Grey literature in a resource-poor setting can be very critical in determining outputs of research activities and knowledge production efforts. This scoping review was unfortunately limited to peer-reviewed publications, which means that a sizable volume of evidence to present a holistic picture of the situation may have been excluded. Additionally, publications in Portuguese, the third official language in West Africa, could not be retrieved for lack of language skills. Guinea Bissau is Portuguese speaking, but we found one English language publication from that 
country. No publications were found from Cape Verde. Given this language limitation, we cannot conclude there were no HPSR publications from Cape Verde or that the one English publication we found from Guinea Bissau is the only possible one. The field of HPSR is very broad and, despite trying to use a wide range of search terms, there is a possibility that we still missed some papers. The value of this study therefore lies in its comparative nature rather than in the absolute numbers. Finally, the study covered a period of 25 years and author institutional affiliations may have changed over this period.

\section{Conclusions}

This first HPSR situational analysis in West Africa examined the general publication trends and sought to identify individuals and institutions involved in HPSR. The results showed a very slow but steady growth in HPSR publications since 2008, with an uneven distribution of output among countries and institutions. Nigerian and Ghanaian researchers produced more than 50\% of the total regional HPSR publications. Francophone West Africa seem to have more non-West African researchers and institutions leading the HPSR agenda, and most Francophones published in English, making it the preferred language for scientific publication. HPSR research and publications in ECOWAS have been growing steadily over time. However, these publications are somewhat dominated by lead researchers affiliated with Northern institutions, especially in the Francophone and smaller Anglophone countries. Though the lead researchers usually have ECOWAS collaborators, it is important that the capacity to lead applied research such as HPSR is strengthened in ECOWAS.

Clearly, there is an urgent need for a critical mass of HPSR producers and consumers within the sub-region. These findings provide a fair idea of which West African institutions and individuals may eventually have the capacity for HPSR training and mentorship. Like many other LMICs, lack of resources (human and financial) has been identified as one of the factors limiting HPSR production in West Africa. Thus, for a resource-poor region, cross-country institutional collaborations that emphasise collaborative research agenda setting among researchers and research consumers within the subregion is critical. Triangulating this collaboration with other Northern partners could further help address the identified challenges. Fortunately, there are some embryonic collaborative research activities within the subregion that could be explored and further developed into a more sustainable South-South collaboration.

\section{Abbreviations}

ECOWAS: Economic Community of West African States; HICs: high-income countries; HPSR: health policy and systems research; LMICs: low- and middleincome countries; WAHO: West Africa Health Organization.
Funding

Publication costs were funded by the International Development Research Centre.

\section{Availability of data and materials}

Data will be made available upon request from the corresponding author.

\section{Authors' contributions}

IAA, AK and SD conceived the article. SD compiled the data. SD, AK and IAA analysed the data. SD led the drafting of the paper, and IAA and AK critically reviewed the various iterations of the manuscript and approved the final version. All authors read and approved the final manuscript.

\section{Competing interests}

The authors have declared that they have no competing interests.

\section{Consent for publication}

Not applicable.

\section{Ethics approval and consent to participate}

Not applicable.

\section{About this supplement}

This article has been published as part of Health Research Policy and Systems Volume 15 Supplement 1, 2017: People and research: improved health systems for West Africans, by West Africans. The full contents of the supplement are available online at https://health-policy-

systems.biomedcentral.com/articles/supplements/volume-15-supplement-1.

\section{Publisher's Note}

Springer Nature remains neutral with regard to jurisdictional claims in published maps and institutional affiliations.

Published: 12 July 2017

\section{References}

1. Kebede D, Soumbey-Alley WE, Asamoah-Odei E, Lusamba-Dikassa PS, Sambo LG. Progress on the health-related MDGs in the African Region. African Health Monitor. 2010;10:10-7.

2. World Health Organization. The World Health Report. Health Systems: Improving Performance. Geneva: WHO; 2000. p. 2000.

3. World Health Organization. The World Health Report 2003: Shaping the Future. Geneva: WHO; 2003.

4. Swanson RC, Cattaneo A, Bradley E, Chunharas S, Atun R, Abbas KM, Best A. Rethinking health systems strengthening: key systems thinking tools and strategies for transformational change. Health Policy Plan. 2012;27(4):54-61.

5. Campbell DM, Redman S, Jorm L, Cooke M, Zwi AB, Rychetnik L. Increasing the use of evidence in health policy: practice and views of policy makers and researchers. Aust N Z Health Policy. 2009;6(1):21.

6. Dobrow MJ, Goel V, Upshur REG. Evidence-based health policy: context and utilisation. Soc Sci Med. 2004;58(1):207-17.

7. Hanney SR, Gonzalez-Block MA, Buxton MJ, Kogan M. The utilisation of health research in policy-making: concepts, examples and methods of assessment. Health Res Policy Syst. 2003;1:2.

8. Innvaer S, Vist G, Trommald M, Oxman A. Health policy-makers' perceptions of their use of evidence: a systematic review. J Health Serv Res Policy. 2002; 7(4):239-44.

9. Bennett S, Ghaffar A, Mills A, Yesudian M, Mandelbaum-Schmidt J. What is health policy and systems research and why does it matter? Briefing Note. 2007;1:1-8.

10. Alliance for Health Policy and Systems Research. What is HPSR? Overview. Geneva: WHO; 2011

11. Remme JH, Adam T, Becerra-Posada F, D'Arcangues C, Devlin M, Gardner C, Mbizvo MT. Defining research to improve health systems. PLoS Med. 2010; 7(11):e1001000.

12. European Commission. The EU Role in Global Health: Communication from the Commission to the Council, the European Parliament, the European Economic and Social Committee and the Committee of the Regions. Brussels: EC; 2010.

13. Global Forum for Health Research. The Ministerial Summit on Health Research: The Mexico Statement on Health Research. Geneva: WHO; 2004. 
14. Global Forum for Health Research. Global Ministerial Forum on Research for Health: Bamako Call to Action. Geneva: WHO; 2008.

15. Task Force on Global Action for Health System Strengthening. Global Action for Health System Strengthening: Policy Recommendations to the G8. Tokyo: Japan Center for International Exchange; 2009.

16. Task Force on Health Systems Research. Informed choices for attaining the Millennium Development Goals: Towards an international cooperative agenda for health-systems research. Lancet. 2004;364:1756.

17. UK Department for International Development. UK Department for International Development (2008) DFID Research Strategy 2008-2013: Working Paper Series: Better Health. London: DFID; 2008.

18. World Health Organization. World Report on Knowledge for Better Health: Strengthening Health Systems. Geneva: WHO; 2004.

19. World Health Organization. World Health Assembly Resolution (WHA58.34) Ministerial Summit on Health Research. Geneva: WHO; 2005.

20. World Health Organization. Report from the Ministerial Summit on Health Research: Identify Challenges, Inform Actions, Correct Inequities. Geneva: WHO; 2005

21. World Health Organization. Executive Board, 124th Session: WHO's Role and Responsibilities in Health Research: Bamako Global Ministerial Forum on Research for Health. Geneva: WHO; 2009.

22. World Health Organization. Scaling Up Research and Learning for Health Systems: Now is the Time: Report of a High Level Task Force, Presented and Endorsed at the Global Ministerial Forum on Research for Health 2008, Bamako, Mali. Geneva: WHO; 2009.

23. World Health Organization. World Health Resolution (WHA63.21). WHO's Role and Responsibilities in Health Research. Geneva: WHO; 2010

24. World Health Organization. World Health Assembly Resolution (WHA63.22). WHO's Role and Responsibilities in Health Research: Draft WHO Strategy on Research for Health. Geneva: WHO; 2010.

25. Bennett S, Adam T, Zarowsky C, Tangcharoensathien V, Ranson K, Evans T, Alliance STAC. From Mexico to Mali: progress in health policy and systems research. Lancet. 2008;372(9649):1571-8

26. El-Jardali F, Jamal D, Ataya N, Jaafar M, Raouf S, Matta C, Smith C. Health policy and systems research in twelve Eastern Mediterranean countries: a stocktaking of production and gaps (2000-2008). Health Res Policy Syst. 2011;9:39.

27. Yao Q, Chen K, Yao L, Lyu PH, Yang TA, Luo F, Liu ZY. Scientometric trends and knowledge maps of global health systems research. Health Res Policy Syst. 2014;12:26

28. Sundewall J, Swanson RC, Betigeri A, Sanders D, Collins TE, Shakarishvili G, Brugha R. Health-systems strengthening: current and future activities. Lancet. 2011;377(9773):1222-3.

29. World Bank. Country and Lending Groups. https://datahelpdesk.worldbank. org/knowledgebase/articles/906519-world-bank-country-and-lendinggroups. Accessed 31 May 2016.

30. Sawyer A. African universities and the challenge of research capacity development. J Higher Educ Africa. 2004;2(1):213-42.

31. Sombié I, Aidam J, Konaté B, Somé TD, Kambou SS. The state of the research for health environment in the ministries of health of the Economic Community of the West African States (ECOWAS). Health Res Policy Syst 2013;11:35.

32. Nwaka S, llunga TB, Da Silva JS, Verde ER, Hackley D, De Vré R, Ridley RG. Developing ANDI: a novel approach to health product R\&D in Africa. PLoS Med. 2010;7(6):e1000293.

33. Arksey H, O'Malley L. Scoping studies: towards a methodological framework Int J Soc Res Methodol. 2005;8(1):19-32.

34. Mills A. Strengthening Health Systems: The Role and Promise of Policy and Systems Research. Alliance for Health Policy and Systems Research. Geneva: WHO; 2004

35. Kirigia JM, Wambebe C. Status of national health research systems in ten countries of the WHO African Region. BMC Health Serv Res. 2006;6:135.

36. Adam T, Ahmad S, Bigdeli M, Ghaffar A, Røttingen JA. Trends in health policy and systems research over the past decade: still too little capacity in low-income countries. PLoS One. 2011;6(11):e27263.

37. Mbondji PE, Kebede D, Zielinski C, Kouvividila W, Sanou I, Lusamba-Dikassa PS. Overview of national health research systems in sub-Saharan Africa: results of a questionnaire-based survey. J R Soc Med. 2014;107 Suppl 1:46-54.

38. United Nations Development Programme. Capacity Development Practice Note. New York: UNDP; 2008
39. Gonzalez Block MA, Mills A. Assessing capacity for health policy and systems research in low and middle income countries. Health Res Policy Syst. 2003;1:1.

40. Olaleye DO, Odaibo GN, Carney P, Agbaji O, Sagay AS, Muktar H, Akanmu S. Enhancement of health research capacity in Nigeria through North-South and in-country partnerships. Acad Med. 2014;89(8):S93-7.

41. Mayhew SH, Doherty J, Pitayarangsarit S. Developing health systems research capacities through north-south partnership: an evaluation of collaboration with South Africa and Thailand. Health Res Policy Syst. 2008;6:8

42. Chandiwana S, Ornbjerg N. Review of North-South and South-South cooperation and conditions necessary to sustain research capability in developing countries. J Health Popul Nutr. 2003:21(3):288-97.

43. Cash-Gibson L, Guerra G, Salgado-de-Snyder VN. SDH-NET: a South-NorthSouth collaboration to build sustainable research capacities on social determinants of health in low-and middle-income countries. Health Res Policy Syst. 2015:13:45.

44. de Solla Price DJ, Beaver D. Collaboration in an invisible college. Am Psychol. 1966;21(11):1011.

45. Godin B, Gingras Y. Impact of collaborative research on academic science. Sci Public Policy. 2000;27(1):65-73.

46. Zuckerman H. Nobel laureates in science: Patterns of productivity, collaboration, and authorship. Am Sociol Rev. 1967;32(3):391-403.

47. Lee S, Bozeman B. The impact of research collaboration on scientific productivity. Soc Stud Sci. 2005;35(5):673-702.

\section{Submit your next manuscript to BioMed Central and we will help you at every step:}

- We accept pre-submission inquiries

- Our selector tool helps you to find the most relevant journal

- We provide round the clock customer support

- Convenient online submission

- Thorough peer review

- Inclusion in PubMed and all major indexing services

- Maximum visibility for your research

Submit your manuscript at www.biomedcentral.com/submit 